\title{
Ethical leadership and work values practices employed by restaurant managers in Quezon Province
}

\author{
Martinez, Jose Romulus A. $\square$ \\ Lyceum of the Philippines University Batangas, Philippines (jommartinez26@gmail.com) \\ Received: 9 November 2021 \\ Available Online: 24 February 2022 \\ Revised: 18 February 2022 \\ Accepted: 24 February 2022 \\ ISSN: 2243-7770 \\ Online ISSN: 2243-7789 \\ OPEN ACCESS
}

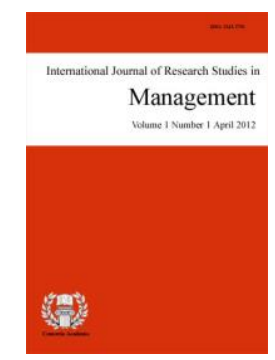

\section{Abstract}

The study examined the existing or current ethical leadership and work values practices employed by restaurant managers in Quezon Province. This includes obtaining the profile of the respondents in terms of age, sex, educational attainment, and number of years in service, determining the ethical practices on leadership in terms of people orientation, fairness, power sharing, ethical guidance, and role clarification and integrity, and the work values on leadership in terms of cognitive, affective, and materials. The study used a questionnaire as the instrument of the study with the restaurant employee as the respondents. The statistical tools used were percentage, frequency distribution, weighted mean, and Cronbach Alpha. Based on the results majority of the restaurant employees are 25 years old and below who belongs in Generation Z, male, and in service for 2- 5 year. Most attained a bachelor's degree for their education. As answered by the respondents, the ethical practices on leadership that they often apply people orientation, power sharing, ethical guidance, and role clarification and integrity; for the work values on leadership, the cognitive values; fairness is sometimes practiced. It was found out that there is a there is significant relationship between assessment in ethical practices on leadership in terms of people orientation, power sharing, ethical guidance and role clarification and integrity and assessment in work values on leadership in terms of cognitive, affective and materials. The researcher proposed a guideline to develop and retain the ethics and work values on leadership to enhance the interpersonal and professional relationship between the managers and the employees.

Keywords: ethical leadership, restaurant managers, work values 


\section{Ethical leadership and work values practices employed by restaurant managers in Quezon Province}

\section{Introduction}

In any type of organization, specifically restaurants, ethical leadership is an important aspect that should be applied by managers, owners, or any higher position in dealing with their employees or subordinates. It has the function to promote the importance of a person's wellbeing in the way that they treat people while they are guiding them to achieve a common goal. On the other hand, there are work values that is also shown by the restaurant managers which sets the tone of the business culture; it can be from the beliefs of the different people collective come together to contribute the ways that any kind of business would work. Through practice of ethical leadership and work values in a restaurant it will reflect to managers' personal being if they are ethical or immoral.

Witzel (2018) stated ethical leadership is the collection of values, morals, and beliefs of an individual and their organizations. Buble (2012) added ethics is the process which influences employees with values, beliefs, and principles that is an extensively part of accepting the norms in an organization. Bachman (2017) discussed that in ethical leadership an individual is behaving conforming to the set of principles and values that the majority recognized in an organization which is a basis for the common good. Langlois (2011) explained the importance of ethical leadership in business that it has a positive effect in hiring employees, product development, and managing the organization. Tang et al. (2014) expressed the role of leaders should have high level of ethical conduct and moral value in shaping their followers' behavior; they also stated that there is essentiality of ethical leadership in the hospitality industry as it will help in the growth and survival of the industry however it remains unclear in the way that ethical leadership influences the employees' intention to stay in the job or leave. In the study of Miao et al. (2013) in the restaurant setting through the application of ethical leadership it shown effectively the reduction of employee misconduct, unruly behaviors, and bullying in the restaurant premises.

Nedelko and Brzozowski (2017) described work values as part of any person's ideas and beliefs which are related for their job or occupation or that includes self-respect, service, honesty and for others there is peace and success. Bourne and Jenkins (2013), work values as a small number of values that collectively come together to make a value system which place greater importance on certain values over another through experience and learning. Askeland et al. (2020) explained work values signify the aspects that an organization operates which connected with morals and norms and signifies preferences, worth and priorities that separate the desirable aspects from undesirable things. In the study of King et al. (2017) it is asserted that work values in the hospitality industry is a motivational booster for the employees' behavior; however, there are no previous studies about work values in the restaurant setting which explains the behavior and work altitudes of the management.

Bartnik et al. (2017) explained that any person has their own characteristics and practices in ethical leadership which includes moral management, and actively influencing each employee to act conscientious according to their ethics and encourage them to act in using their moral. Hussein et al. (2017) stated that there is an increasing awareness on ethical leadership however there are management in organizations which are found ethically ill and irresponsible. Starrat (2013) added that there are moral and ethical issues of a manager and they face several dilemmas which affect them being the role model or the organization. While, based from statement of Naimi et al. (2017) people already have their own values that they apply while working in an organization however it takes a long period of time to teach new values; in particular, when a person is not willing to learn. Kim and Brymer (2011) explained that in the restaurant setting ethical leadership is highly relevant because of the noticeable decrease of travelers that visits a certain destination; therefore, in this current situation the leadership roles of restaurant managers cannot be stressed.

42 Consortia Academia Publishing (A Partner of Tourism Educators and Movers of the Philippines) 
Grace (2008) discusses the theory of ethical leadership that it is composed of 4- V's model that are ${ }_{3}$ values, vision, voice, and virtue; in which values and vision give the purpose and direction, the voice gives values and vision its principles of being dynamic, and virtue is part of commitment, principles, and lastly sensitivity to relationship, for a common good. In the study of Kalshoven et al. (2010) they emphasized the factors in ethical leadership which are people orientation, fairness, power sharing, concern for sustainability, ethical guidance, role clarification, and integrity. Zydziunaite (2018) studied leadership values and stated that there are three concepts which are personality, interaction and relationship, and action which a responsible leader should act upon in an organization. According to Elizur et al. (2008) as cited by Rao and Urs (2017) about the importance of life domains in different cultural group, they distinguished three modalities of work values which are instrumental or also called as material, affective and cognitive.

Every person has their own ethics and values they apply in their everyday life; thus, this ethics and values also being applied by managers of the restaurants as the leader which has the key role to guide their subordinates to attain a common goal. The researcher would like to assess the application of ethics and values in the organization. Moreover, this is projected to pave a way toward to improve the researcher's knowledge in the managerial supervision.

\subsection{Objective of the Study}

This study determined ethical leadership and work values employed by managers of the restaurants in Quezon province. Specifically, it presented the profile of the respondents in terms of age, sex, educational attainment, and the number of years in service; determined the ethical leadership practices in terms of people orientation, fairness, power sharing, ethical guidance, role clarification, and integrity; and determined the work values on leadership in terms of cognitive, affective, and materials. Tested also the significant difference on the responses when grouped according to profile and tested the significant relationship between the ethical leadership practices and work values. A guideline on ethical leadership and work values was proposed that was based on the result of the study.

\section{Methodology}

Research Design - This study used descriptive research to assess the ethical leadership practices and work values of the restaurant managers. Descriptive method is a technique used by the researcher to identify the present condition and/ or discussion of the facts which are occurring at the present time. This research design uses numerical coefficients and statistics to establish the extent of occurrences of each event in the community (Kara, 2015).

Participant of the Study - To avoid bias, the study was participated by three hundred eighty- five restaurant employees who have the authority and capability to answer the ethical leadership and work values practices employed by their restaurant manager. The restaurants were operating as a casual dining restaurant which implements a casual dining service that according to Pearlman (2013), is a food establishment which has a table service. The server takes the order while the customer or guest is seated at the table where the meal will be brought. The restaurants are free standing entity or not operating in any mall establishment; open for customers dine- in or take out while in COVID- 19 pandemic and applying its protocols, that according to the Inter- Agency Task Force as cited by the Department of Trades and Industry (2020), there should be proper sanitation and distancing of tables and chairs, and has dividers. There are floor markings for queuing, proper ventilation, contactless order- taking, and disinfects the establishment every 30 minutes; and located at the highly urbanized, first class and second-class municipalities of Quezon Province that are accessible to the researcher. Purposive sampling technique was used in the selection of the respondents which Black (2010) defined this technique that the researcher relies on their own judgment in selection of the participants in the study.

Data Collection Instrument - The researcher used a modified questionnaire based from the study ethical 
leadership at work of Kalshoven, Den Hartog, and De Hoogh (2010); and from Don Elizur that was used by Rao and Urs (2017) on their study regarding work values of Generation Y work force. The questionnaire was in three parts: Part $\mathrm{I}$ is the demographic profile of the respondents in terms of age, sex, educational attainment, and number of years in service; Part II consists of the ethical leadership practices in terms of people orientation, fairness, power sharing, ethical guidance, role classification, and integrity; and Part III includes the work values in terms of cognitive, affective, and materials. Simple percentage method was used to measure up proportions of the frequency distribution to the total number of responses in terms of the profiles of the respondents. A fivepoint Likert scale was used ranging from Never to Always for the ethical leadership practices and the work values

Data Gathering Procedure - Upon the approval of research instrument and permission to undertake the study, the researcher coordinated with the manager or supervisor to allow the employees of the restaurants in Quezon Province and informed them that they are included as the participants of the study. An explanation of the purpose of the study and its importance was facilitated. After the acceptance, there were restaurants where the researcher personally conducted the administration of the survey, and there were restaurants that used of a Google form. The researcher waited for the completion of the questionnaire. Immediately after the survey, the accomplished questionnaire was gathered and checked for completeness.

Data Analysis - To perform data analysis, the following statistical tools were used. Frequency and percentage distribution were used to describe the demographic profile of the respondents. Weighted mean and ranking were used to assess the ethical practices on leadership and work values on leadership. The result of Shapiro-Wilk Test revealed that p-values of major variables are less than 0.05 which means that the data set is not normally distributed. Therefore, Mann-Whitney $U$ test for two groups and Kruskal Wallis test for three groups were used as part of the non-parametric tests to determine the significant differences. Likewise, Spearman rho was used to test the significant relationship between ethical practices on leadership and work values on leadership. The following Likert Scale was used in assessing the variables: 4.50 - 5.00 -Always; 3.50 - 4.49 -Often; 2.50 - 3.49 - Sometimes; 1.50 - 2.49 -Seldom; 1.00 - 1.49 -Never. In addition, all data were treated using a statistical software known as PASW version 26 to further interpret the result of the study using an alpha level of 0.05 .

Ethical Consideration - There was confidentiality in conducting the survey. Name of the respondents neither their identity was not revealed. Only the information and data gathered was used in the study. The researcher asked permission of the authors of the previous study to use and modify their instrument of the study for the use of the foregoing research.

\section{Results and Discussion}

Table 1

Percentage Distribution of the Respondents Profile

\begin{tabular}{|c|c|c|c|}
\hline Profile Variables & Items & Frequency & $(\%)$ \\
\hline \multirow[t]{4}{*}{ Age } & 25 years and below $($ Gen $Z)$ & 199 & 51.80 \\
\hline & 26- 41 years old (Gen Y) & 169 & 44.00 \\
\hline & $42-56$ years old $($ Gen $X)$ & 15 & 3.90 \\
\hline & 57 years old and above (Baby Boomers) & 1 & 0.30 \\
\hline \multirow[t]{2}{*}{ Sex } & Male & 205 & 53.40 \\
\hline & Female & 179 & 46.60 \\
\hline Educational & Academe & 44 & 11.4 \\
\hline \multirow[t]{6}{*}{ Attainment } & Health and Medicine & 27 & 7 \\
\hline & Public Officer & 30 & 7.8 \\
\hline & Engineering and Architect & 29 & 7.5 \\
\hline & Police/Military Service & 35 & 9.1 \\
\hline & Hospitality Industry & 68 & 17.7 \\
\hline & Others & 152 & 39.5 \\
\hline No. of Years in & 2-5 Years & 194 & 50.5 \\
\hline \multirow[t]{2}{*}{ Service } & 5-10 Years & 45 & 11.7 \\
\hline & 11 Years and above & 13 & 3.4 \\
\hline
\end{tabular}

44 Consortia Academia Publishing (A Partner of Tourism Educators and Movers of the Philippines) 
Table 2 presents the profile of the respondents in terms of age, sex, educational attainment and number of years in service. In terms of age, majority of the respondents are 25 years and below (Gen Z) with 199 or 51.80 percent followed by 26- 41 years old (Gen Y) with 169 or 44 percent and the lowest is 57 years old and above (Baby Boomers) with 1 respondent or .30 percent. It appears that the age bracket of 25 years and below belongs to Generation Z, got the highest number of employees working in the restaurants followed by the ages $26-41$ or the Generation $\mathrm{Y}$ because at this age, they are just entering the workforce, they can be flexible with their schedule or working as part time, can work under pressure, and easily adapt in the work environment; and since they already started in the job as a restaurant employee their skills developed in that kind of career.

From the research of Jang and Kandampully (2018) 37 percent of the restaurant employees are in the age between 20 and 29 years old, and 49 percent are in the age between 30 and 39 years old. Based from result of the study of Sobaihet et al. (2010), there is greater number of restaurant employees which are in the age of 18 to 24 (40) and 25 to 34 (39); they concluded that many young people spend their time working as part- time before they engage themselves as full- time employees. In the study of Generation Z by Harris (2020), it concluded that workers at this age are entering in the workforce from various industries which they are still analyzing their work culture and environment, therefore they should be provided with sufficient trainings that will ensure the development of their abilities and capabilities. Naim and Lenka (2017) concluded that for Generation Y, still there are competencies that should be developed which would strengthen their engagement, commitment, and intention to stay in the organization.

In terms of sex, majority of the respondents are male with 205 or 53.40 percent, female with 179 or 46.60 percent. The study reveals that dominantly male has more population as the employees of restaurant than its female counterpart. Hence, intense labor masculinity is much needed most especially in the part of moving or lifting equipment, and the application of practical skills. In the study of Nasyira et al. (2014) of the predictors of intention to stay of restaurant employees the dominant sex is male with 62.5 percent whereas the 37.5 percent represents the female employees. Bi et al. (2021) added that in their study of stress in frontline restaurant employees, it revealed that 195 or 64.4 percent of the respondents are male and the female respondents got 107 or 35.4 percent. Pinar et al. (2011) emphasized that male dominates the hospitality industry in the reason of the industry requires long hours of work and have much degrees of mobility; they added that it is also part of a culture that the society do not want to see females working in an environment which lifts heavy loads and working for long hours. Petrovic et al. (2014) stressed male employees enters the restaurant industry because the working condition is favorable for them to apply their physical capabilities.

In terms of educational attainment, most of the respondents are bachelor's degree with 191 or 49.7 percent followed by high school with 136 or 35.4 percent and the lowest is master's degree with 4 or 1 percent. It shows that the employees who are bachelor's degree and high school graduates are great in number; which at this educational attainment they are in qualified for the job such as an entry level, enhancing skills, and gaining experience. Chahab et al. (2021) studied the impacts of job standardization of restaurant employees which it resulted that majority of the restaurant employees are bachelor's degree graduate with 185 or 63.4 percent. Cuevas et al. (2020) studied on the green practices of selected restaurants which from its respondents' profile, it shows that college graduates have the highest percentage which is 74.4 percent; while high school graduates are 25.6 percent. According to Alexander and Pyyamoli (2014), college graduates have more education and more qualified in working in various industries; they also understand the situation of the environment which they apply their skills while enhancing it.

In terms of number of years in service, majority of the respondents are 2- 5 years in service with 194 or 50.5 percent followed by 1 year and below with 132 or 34.4 percent and the lowest is 11 years and above with 13 or 3.4 percent. The study reveals that the restaurant employees who are employed 2- 5 years and 1year and below is the highest. It indicates that the restaurant employees who are employed at that year bracket are honing themselves in the foodservice industry and they are in the entry level workers of the restaurants. Chen and Ayoun (2021) studied the restaurant culture in workplace regarding humor and job embeddedness which it resulted that 
the average restaurant tenure in the United States is 2 years and 7 months, and in China there is 1 year and 11 months. While in the study of Kim and Qu (2018) about the effects of experienced customer incivility on employees' behavior, more than 1 to 4 years got the highest number of the answer of the respondents. In the research about motivational effects of empowerment on employees' organizational commitment of Kim et al. (2011), the tenure of the employees of 241 out of 330 answered less than or equal to 5 years with 73 percent.

Table 2

Factors on Ethical Leadership Practices

\begin{tabular}{lllll}
\hline \multicolumn{1}{c}{ Indicators } & Cronbach Alpha & Weighted Mean & Verbal Interpretation & Rank \\
\hline 1. People Orientation & 0.847 & 4.13 & Often & 2 \\
2. Fairness & 0.870 & 3.26 & Sometimes & 5 \\
3. Power Sharing & 0.852 & 3.69 & Often & 4 \\
4. Ethical Guidance & 0.967 & 4.11 & Often & 3 \\
5. Role Clarification \& Integrity & 0.864 & 4.20 & Often & \\
Composite Mean & 3.88 & 3.88 & Always \\
Legend: $4.50-5.00=$ Always; $3.50-4.49=$ Often; $2.50-3.49=$ Moderately Sometimes; $1.50-2.49=$ Seldom; $1.00-1.49$ \\
= Never
\end{tabular}

Table 2 presents the summary of table for the assessment in ethical practices on leadership with the over- all mean of 3.88 verbally interpreted as often practiced. Role clarification and integrity ranked first (4.20) followed by people orientation (4.13) and third, ethical guidance (4.11). All items were rated as often practiced. The restaurant employees exhibited that their managers frequently apply role clarification and integrity in associating with them. It indicates that the employees of the restaurants are knowledgeable with their duties and responsibilities, and they deal with their daily operations with moral, ethical and with honesty.

Aga et al. (2016) discussed that in role clarification, the members of the organization is assigned to their respected duties and responsibilities; through this, there is communication and a better understanding of the role that is expected from each member. From the study of Shuffler et al. (2011) team development interventions in organizations, in goal setting team building role clarification helps every individual to be motivated in finding their purpose. Cleary et al. (2013) defined integrity as the commitment to the five fundamental values such as trust, honesty, responsibility, trust, and fairness which flows the principles of behavior which translate ideas into actions. Huberts (2018) sited another view for integrity is professional wholeness or responsibility which every person exercises professionalism to their tasks in full adequacy, and taking account all relevant interests. However, power sharing ranked low (3.69) which was rated as often practiced. And lowest is fairness (3.26) which was rated as sometimes practiced.

Interestingly, as the response of the restaurant employees, only fairness is practiced by the managers from time to time. It indicates that the managers have their own bias towards the restaurant itself, the operation, and the employees. Choi and Rainey (2013) stated that as organization employs fairness or fair treatment with all its members it can enhance the perception of diversity and difference between individual can be managed. In the study about employees' perceptions by Komodromos (2014), fairness is considered has a link of outcomes which are important for both the employees and the employing organization; these outcomes are trust, job satisfaction, cooperative work behaviors, and organizational commitment. And as recommended by Cabaraban and Borbon (2021), they suggest further improvement on flexible working hours and flexible working arrangements, to prioritize productivity over working hours, regular job performance evaluations which in return will practice fairness among the employees.

Table 3 presents the summary for assessment in work values in leadership with the over- all mean of 4.23 verbally interpreted as often practice. Cognitive ranked the highest (4.27) followed by affective (4.23) and the lowest material (4.20). All items were rated as often practice. The restaurant employees imply that their manager uses their cognitive values more often, which specifies that they are inclined in behavior, attitude, beliefs, and values. 
Table 3

Work Values on Ethical Leadership

\begin{tabular}{lllll}
\hline \multicolumn{1}{c}{ Indicators } & Cronbach Alpha & Weighted Mean & Verbal Interpretation & Rank \\
\hline 1.Cognitive & 0.934 & 4.27 & Often & 1 \\
2. Affective & 0.831 & 4.23 & Often & 2 \\
3. Material & 0.940 & 4.20 & Often & 3 \\
Composite Mean & 4.23 & 4.23 & Often & \\
\hline Legend: $4.50-5.00=$ Always; $3.50-4.49=$ Often; $2.50-3.49=$ Sometimes; $1.50-2.49=$ Seldom; $1.00-1.49=$ Never
\end{tabular}

Pryce (2014) stressed that in part of work values; cognitive represents expressions of the different needs of a person working that includes monetary security, social interaction, intellectual stimulation, esteem, status, and self- actualization. Nikulina and Khomenko (2015) explained that cognitive in management is a diverse toolkit of modern organization that helps employees understands what to do and to achieve goals. Jain and Jappesen (2013) stated that cognitive has an important role in managing a business; and has a role for the people to impart creativity, exploit knowledge, and values for the organization objectives. Based from the result, the material work values are the least described as often. It can be explained that though this aspect of work values is important, that can be in promotion, benefits, and compensation, yet having the abilities to do the duties and responsibilities in the job performance along with the safety and security assures that the restaurant employees is practicing their moral and values. Winter and Jackson (2015) stated that that material in work values such as salary and benefits is the least important among cognitive and affective work values. Since, Diaz and Arroyo (2017) added that material values focus on the importance of possessing the material goods to achieve a certain status while having self- evaluation in comparing with the life and abilities to others.

Table 4

Differences in ethical practices on leadership and work values on leadership when grouped to profile variables

\begin{tabular}{|c|c|c|c|}
\hline Age & $\mathrm{U} / \lambda 2 \mathrm{c}$ & p-value & Interpretation \\
\hline \multicolumn{4}{|l|}{ Ethical Practices on Leadership } \\
\hline People Orientation & 0.022 & 0.989 & Not Significant \\
\hline Fairness & 2.169 & 0.338 & Not Significant \\
\hline Power Sharing & 0.856 & 0.652 & Not Significant \\
\hline Ethical Guidance & 0.355 & 0.837 & Not Significant \\
\hline Role Clarification \& Integrity & 0.142 & 0.931 & Not Significant \\
\hline \multicolumn{4}{|l|}{ Work Values on Leadership } \\
\hline Cognitive & 5.730 & 0.057 & Not Significant \\
\hline Affective & 0.137 & 0.934 & Not Significant \\
\hline Materials & 3.262 & 0.196 & Not Significant \\
\hline \multicolumn{4}{|l|}{ Sex } \\
\hline \multicolumn{4}{|l|}{ Ethical Practices on Leadership } \\
\hline People Orientation & 15379.0 & 0.006 & Significant \\
\hline Fairness & 17293.5 & 0.330 & Not Significant \\
\hline Power Sharing & 17888.5 & 0.671 & Not Significant \\
\hline Ethical Guidance & 14794.0 & 0.001 & Significant \\
\hline Role Clarification \& Integrity & 17454.5 & 0.408 & Not Significant \\
\hline \multicolumn{4}{|l|}{ Work Values on Leadership } \\
\hline Cognitive & 17645.0 & 0.515 & Not Significant \\
\hline Affective & 17680.5 & 0.535 & Not Significant \\
\hline Materials & 18263.0 & 0.937 & Not Significant \\
\hline \multicolumn{4}{|l|}{ Educational Attainment } \\
\hline \multicolumn{4}{|l|}{ Ethical Practices on Leadership } \\
\hline People Orientation & 3.392 & 0.335 & Not Significant \\
\hline Fairness & 2.449 & 0.484 & Not Significant \\
\hline Power Sharing & 5.266 & 0.153 & Not Significant \\
\hline Ethical Guidance & 1.187 & 0.756 & Not Significant \\
\hline Role Clarification \& Integrity & 6.473 & 0.091 & Not Significant \\
\hline \multicolumn{4}{|l|}{ Work Values on Leadership } \\
\hline Cognitive & 1.852 & 0.604 & Not Significant \\
\hline Affective & 0.327 & 0.955 & Not Significant \\
\hline Materials & 2.112 & 0.549 & Not Significant \\
\hline
\end{tabular}




\begin{tabular}{llll}
\hline No. of years in Service & & & \\
Ethical Practices on Leadership & 13.798 & 0.003 & Significant \\
People Orientation & 4.442 & 0.218 & Not Significant \\
Fairness & 4.708 & 0.195 & Not Significant \\
Power Sharing & 18.233 & $<0.001$ & Significant \\
Ethical Guidance & 9.222 & 0.026 & Significant \\
Role Clarification \& Integrity & & & \\
\hline Work Values on Leadership & 8.325 & 0.040 & Significant \\
Cognitive & 6.846 & 0.077 & Not Significant \\
Affective & 9.920 & 0.019 & Not Significant \\
Materials & & &
\end{tabular}

Legend: Significant at p-value $<0.05$

As presented in the table above, there is significant difference in assessment in ethical practices on leadership in terms of people orientation and ethical guidance when grouped to sex since the computed $p$ value is less than 0.05 level of significance. Thus, assessment in ethical practices on leadership in terms of people orientation and ethical guidance differs when grouped to sex. Male respondents had higher assessment in ethical practices on leadership in terms of people orientation and ethical guidance. The male restaurant employees have the higher assessment with people orientation and ethical guidelines since they are more exposed in the foodservice operation, they are more likely guided in interacting with their colleagues and customers while they are preparing or serving the food in their workplace. Moreover, they perform their tasks at work, well oriented with people and ethically guided.

Based from the study of Haley- Lock and Ewert (2011) in workplace practice and workforce composition, male employees are more likely qualified and experienced for the waiter or server position which interaction with customers are being done. In the research study of Kacmar et al. (2011) in fostering good citizenship through ethical leadership, it is expected for male employees to achieve greater work- related outcomes through demonstration of the masculine behavior that is task- focused. As stated in the study of Ekore (2013) of the personality dimensions and work ethics it stated that work ethics varied by gender with male demonstrates stronger work ethical values.

As presented above, there is a significant difference in assessment in ethical practices on leadership in terms of people orientation, ethical guidance and role clarification and integrity when grouped to number of years in service since the computed $\mathrm{p}$ value is less than 0.05 level of significance. Thus, assessment in ethical practices on leadership in terms of people orientation, ethical guidance, and role clarification and integrity differs when grouped to number of years in service. 2- 5 years in service had higher assessment in ethical practices on leadership in terms of people orientation, ethical guidance, and role clarification. From the result, as the employees of the restaurant render a longer service in the management, in a certain point, they already develop their values and ethics in dealing with people and understand their role in the organization.

Based from the study of Liao and Chuang (2007) the longer the service that is being provided by an employee, social and emotional relationships are built. In addition, being friendly, playful, and attentive to the customers are also provided. Kloutsiniotis and Mihail (2020) stated the longer an employee is working in the organization there is an opportunity for them to participate in the decision-making process; they will feel a trusting work environment and feel that there is organizational justice. Ferdem and Atsam (2015) added, the longer the service of an employee they are already tested for their honesty, truthfulness, and contentedness.

As presented above, there is a significant difference in assessment in work values on leadership in terms of cognitive when grouped to number of years in service since the computed p value is less than 0.05 level of significance. Thus, assessment in work values on leadership in terms of cognitive differs when grouped to number of years in service. 2- 5 years in service had higher assessment in work values on leadership in terms of cognitive. It indicates that having a longer service of the restaurant employees, the cognitive factor in work values is already developed. It pertains to the restaurant employees' progression in terms of work independence 
and confidence, developed their self-esteem, and able to interact with the high-ranking positions and as well as the customers based on their working experience.

Gkorezis et al. (2011) expressed that long- term employees maintain high quality relationships with their supervisors. Jiang et al. (2017) explained that there is a positive relationship between the employees who stay for long term with the management and the business which they have the better capacity to utilize adaptability resources and to solve work related problems. Agyemang and Ofie (2013) added employees with longer tenure in a business have a higher level of organizational commitment

\section{Table 5}

Proposed Guidelines for Ethical Leadership and Work Values for Restaurant Management

\begin{tabular}{|c|c|c|}
\hline Key Result Area/ Objective & Guidelines & Desired Outcome \\
\hline $\begin{array}{l}\text { People Orientation } \\
\text { For the restaurant managers to } \\
\text { empathize their employee when } \\
\text { they have personal or } \\
\text { work-related problems }\end{array}$ & $\begin{array}{l}\text { The restaurant manager should talk and understand } \\
\text { the significant issues or problems of their employees } \\
\text { by putting oneself to someone's shoe. }\end{array}$ & $\begin{array}{l}\text { The restaurant employees will } \\
\text { be comfortable working with } \\
\text { their manager they could } \\
\text { personally talked about self } \\
\text { related issues. }\end{array}$ \\
\hline $\begin{array}{l}\text { Fairness } \\
\text { For exercising and practicing the } \\
\text { role of just in the daily restaurant } \\
\text { operation }\end{array}$ & $\begin{array}{l}\text { The restaurant manager should focus on reaching } \\
\text { their goal while considering the contribution that is } \\
\text { given by the employees through their work. }\end{array}$ & $\begin{array}{l}\text { The restaurant employees will } \\
\text { feel the belongingness and their } \\
\text { importance while the restaurant } \\
\text { is on its growth. }\end{array}$ \\
\hline $\begin{array}{l}\text { Power Sharing } \\
\text { For the restaurant employees to } \\
\text { share their ideas in the } \\
\text { improvement of the restaurant } \\
\text { operation }\end{array}$ & $\begin{array}{l}\text { The restaurant managers should allow their } \\
\text { employees in sharing their comments and suggestions } \\
\text { during the decision-making process. }\end{array}$ & $\begin{array}{l}\text { The employees will feel that } \\
\text { they have essential } \\
\text { belongingness and have an } \\
\text { important role in the restaurant. }\end{array}$ \\
\hline $\begin{array}{l}\text { Ethical Guidance } \\
\text { For the enhancement of the } \\
\text { culture of integrity in the } \\
\text { restaurant }\end{array}$ & $\begin{array}{l}\text { The restaurant manager should discuss the integrity } \\
\text { issues that is occurring in the business }\end{array}$ & $\begin{array}{l}\text { The employees will be aware } \\
\text { of the ethical values that should } \\
\text { be applied while working in the } \\
\text { restaurant }\end{array}$ \\
\hline
\end{tabular}

Role Clarification \& Integrity For the restaurant employees to believe in the aspects that the management conveys
The restaurant managers should keep their promises to their employees.
The restaurant employees will whole heartedly give trust to their employees

The employees will certainly remain employed in the restaurant for long term. through giving the right compensation and/ or benefits.

The restaurant managers should be consistent of being fair and just through giving each and every employee their equal rights.
The restaurant employees will give trust to their managers, and there will be no unfairness issues that will arise
The restaurant manager should offer benefits such as overtime pay, food allowance and the likes to their employees
The employees will give more support and engagement in the restaurant.

\section{Conclusion and Recommendation}

Majority of the restaurant employees are 25 years old and below who belong in Generation Z, mala, and in service for 2- 5 years. Most attained a bachelor's degree for their education. For the ethical leadership, it is often practiced by their managers to care about the employees; they consider their decisions from the recommendations that are reported, they clarify the guidelines for integrity, and they clarify the business priorities. However, the restaurant managers sometimes mainly focus in reaching their goals. 
For the work values on leadership, the restaurant employees responded that it is an often practiced by their manager in showing interest in their job; keep a good company while working; and ensures meaningful work. It was found out that there is significant difference in assessment in ethical practices on leadership in terms of people orientation and ethical guidance when grouped to sex; while there is also a significant difference in assessment in ethical practices on leadership in terms of people orientation, ethical guidance and role clarification and integrity, and work values on leadership in terms of cognitive when grouped to number of years in service.

It was found out that there is significant relationship between assessment in ethical practices on leadership in terms of people orientation, power sharing, ethical guidance and role clarification and integrity and assessment in work values on leadership in terms of cognitive, affective and materials. The researcher proposed a guideline for the ethical leadership and work values practices for the managers that can be the basis in dealing with their employees in the restaurant. The respondents who belong to Generation $\mathrm{Z}$ should enroll for further studies since they are the restaurant employees; consequently, they will have an opportunity to become restaurant managers. The restaurant managers may continue the healthy relationship within the organization in applying the aspects of ethical leadership while working with their employees. In that way, the employees will be guided with the code of ethics and integrity that they should practice in the restaurant.

The restaurant managers may keep on practicing the work values on leadership that they apply in their workplace; having this such application would ensure that the employees are working accordingly without pressure. The restaurant managers may also emphasize on exercising fairness as part of their application on ethical leadership and work values in their workplace; in this way, there will be justice in the treatment of every employee; and the managers will be recognized as more respected and professional leaders. Proposed guideline for the ethical leadership and work values practices may be tabled for discussion. Future researchers may conduct a similar study emphasizing ethical leadership and work values with the use of other instruments, and use this work as reference material and a guide for future related researches.

\section{References}

Aga, D. A., Noorderhaven, N., \& Vallejo, B. (2016). Transformational leadership and project success: The mediating role of team-building. International Journal of Project Management, 34(5), 806-818. https://doi.org/10.1016/j.ijproman.2016.02.012

Agyemang, C. B., \& Ofei, S. B. (2013). Employee work engagement and organizational commitment: A comparative study of private and public sector organizations in Ghana. European Journal of Business and Innovation Research, 1(4), 20-33. Retrieved from: https://bit.ly/2ZpXJXG

Alexander, R., \& Poyyamoli, G. (2014). The effectiveness of environmental education for sustainable development based on active teaching and learning at high school level - a case study from Puducherry and Cuddalore regions, India. Journal of Sustainability Education, 7. Retrieved from https://citeseerx.ist.psu.edu/viewdoc/download?doi=10.1.1.662.6909\&rep=rep1\&type=pdf

Askeland, H., Espedal, G., Lovaas, B. J., \& Sirris, S. (2020). Understanding work values work. Switzerland: Palgrave Macmillan.

Bachman, B. (2017). Ethical leadership in organizations. Switzerland: Springer International Publishing.

Bartnik, R., Haney, M., Ko, C., \& Ma, J. (2017). Ethical leadership: an integrative review and future research agenda. Mingu Kang, School of Management, Zhejiang University.

Black, K. (2010). Business statistics: cotemporary decision making $6^{\text {th }}$ edition. United States: John Wiley \& Sons.

Bourne, H. \& Jenkins, M. (2013). Organizational values: a dynamic perspective. University of Bristol \& Cranfield School of Management, United Kingdom.

Buble, M. (2012). Interdependence of organizational culture and leadership styles in large firms. Management-Journal of Contemporary Management Issues, 17(2), 85-97.

Cabaraban, L. A., \& Borbon, N. M. D. (2021). Work life balance among hotel employees in Cagayan de Oro

50 Consortia Academia Publishing (A Partner of Tourism Educators and Movers of the Philippines) 
Ethical leadership and work values practices employed by restaurant managers in Quezon Province

City during COVID-19 pandemic, Misamis Oriental. International Journal of Research Studies in Management, 9(4), 63-79. https://doi.org/10.5861/ijrsm.2021.m7738

Chehab, O., Ilkhanizadeh, S., \& Bouzari, M. (2021). Impacts of Job Standardisation on Restaurant Frontline Employees: Mediating Effect of Emotional Labour. Sustainability, 13(3), 1525. https://doi.org/10.3390/su13031525

Chen, H., \& Ayoun, B. (2021). Does National Culture Matter? Restaurant Employees' Workplace Humor and Job Embeddedness. Journal of Hospitality \& Tourism Research, 10963480211027927. https://doi.org/10.1177/10963480211027927

Choi, S., \& Rainey, H. G. (2013). Organizational Fairness and diversity management in public organizations: does fairness matter in managing diversity? Review of Public Personnel Administration, Sage Publication. Retrieved from https://citeseerx.ist.psu.edu/viewdoc/download?doi=10.1.1.977.2476\&rep=rep1\&type=pdf

Cuevas, J. C., Indicio, M. J., Reyeg, M. J., \&Mandigma, E. (2020). Green practices of selected restaurants in Solenad, Nuvali, Sta. Rosa, Laguna, Philippines. Ioer International Multidisciplinary Research Journal, Vol.2, Nov. 3, Sept., 2020. Retrieved from https://bit.ly/30NbeAX

Department of Trade and Industry, (2020). IATF Approves Health Protocols for Dine- in Operation. Retrieved from https://www.dti.gov.ph/archives/news-archives/health-protocols-for-dine-in-operations/

Diaz, R. P., \& Arroyo, J. C. (2015). Material values: a study of some antecedents and consequences. Universidad Anahuac, Mexico/ Universidad Popular Autonoma del Estado de Puebla, Mexico.

Ekore, J. O. (2013). Machievallian personality dimensions and work ethics among bank employees in Nigeria. Nigerian Journal of Applied Psychology, Department of Guidance Counceling, University of Ibadan. Retrieved from https://bit.ly/3GfQpOW

Elizur, D., Kantor, J., Yaniv, E., \& Sagie, A. (2008). Importance of life domains in different cultural groups. The American journal of psychology, 121(1), 35-46. https://doi.org/10.2307/20445442

Erdem, F., \& Atsan, N. (2015). Trust based relationships between family members and long-term employees of family-owned SMEs. International Business Research, 8(4), 223. https://doi.org/10.5539/ibr.v8n4p223

Gkorezis, P., Hatzithomas, L., \& Petridou, E. (2011). The impacts of leader's humor on employees' psychological empowerment: the moderating role of tenure. Journal of Managerial Issues, Vol. 23, Number 1, Spring 2011: 83- 95. Retrieved: https://ikee.lib.auth.gr/record/271235/files/JMI.pdf

Grace, B. (2008). Ethical leadership. Seattle: Center for Ethical Leadership.

Haley- Lock, A. \& Ewert, S. (2011). Serving men and mothers: workplace practices and workforce composition in two US restaurant chains and states. Community, Work, and family, 14(3) 387- 404. URL: http://www.hillkm.com/yahoo_site_admin/assets/docs/Serving_men_and_mothers.347100445.pdf

Harris, K. (2020). A generation of workers: preparing for generation $z$ in the workplace. Scholar Commons, University of South Carolina. URL: https://scholarcommons.sc.edu/cgi/viewcontent.cgi?article=1338\&context=senior theses

Huberts, L. W. J. C. (2018). Integrity: what it is and why it is important. Public Integrity, 20: S18- S32, 2018. Retrieved from https://www.tandfonline.com/doi/pdf/10.1080/10999922.2018.1477404

Hussein, N., Madanchian, M., Noordin, F., \&Taherdoost, H. (2017). The impact of ethical leadership on leadership effectiveness among SMEs in Malaysia. Faculty of Business and Management, UniversitiTeknologi MARA (UiTM), Malaysia.

Jain, A. K., \& Jappesen, H. J. (2013). Knowledge management practices in a public sector organization: the role of leader's cognitive styles. Journal of Knowledge Management, 17(3), 347-362. https://doi.org/10.1108/JKM-11-2012-0358

Jang, J., \& Kandampully, J. (2018). Reducing employee turnover intention through servant leadership in the restaurant context: a mediation study of affective organizational commitment. International Journal of Hospitality and Tourism Administration. Retrieved from https://bit.ly/2XItvOT

Kacmar, K. M., Bachrach, D. G., Harris, K. J., \&Zivnuska, S. (2011). Fostering good citizenship through ethical leadership: exploring the moderating role of gender and organizational politics. Journal of Applied Psychology, 96(3), 633- 642. URL: http://tarjomefa.com/wp-content/uploads/2016/09/5254-English.pdf 
Kalshoven, K., Den Hartog, D. N., \& De Hoogh, A. H. B. (2010). Ethical leadership at workquestionnaire $(E L W)$ : development and validation of a multidimensional measure.Untrecht University Ethics Institute, University of Amsterdam Business School, University of Amsterdam Work and Organizational Psychology, The Netherlands.

Kim, H., \& Qu, H. (2019). The effects of experienced customer incivility on employees' behavior toward customers and coworkers. Journal of Hospitality \& Tourism Research, 43(1), 58-77. https://doi.org/10.1177/1096348018764583

Kim, H., Rhou, Y., Topcuoglu, E., \& Kim, Y. G. (2020). Why hotel employees care about Corporate Social Responsibility (CSR): Using need satisfaction theory. International Journal of Hospitality Management, 87, https://doi.org/10.1016/j.ijhm.2020.102505

Kim, W. G., \& Brymer, R. A. (2011). The effects of ethical leadership on manager job satisfaction, commitment, behavioral outcomes, and firm performance. International Journal of Hospitality Management, 30(4), 1020-1026. https://doi.org/10.1016/j.jhm.2011.03.008

King, C., Murillo, E., \& Lee, H. (2017). The effects of generational work values on employee brand attitude and behavior: A multi-group analysis. International Journal of Hospitality Management, 66, 92-105. https://doi.org/10.1016/j.ijhm.2017.07.006

Kloutsiniotis, P. V., \& Mihail, D. M. (2020). The effects of high-performance work systems in employees' service-oriented OCB. International Journal of Hospitality Management, 90, https://doi.org/10.1016/j.ijhm.2020.102610

Komodromos, M. (2014). Employees'perception of trust, fairness, and the management of change in three private universities of Cyprus. Journal of Human Resources Management and Labor Studies, June 2014, Vol. 2., No. 2, pp. 35- 54. Retrieved from https://bit.ly/2Zf3zuy

Langlois, L. (2011). The anatomy of ethical leadership. Edmonton: AU Press, Athabasca University

Liao, H. \& Chuang, A. (2007). Transformation service employees and climate: a multilevel, multisource examination or transformational leadership in building long- term service relationships. Journal of Applied Psychology, 2007, Vol. 92, No. 4, 1006- 1019. Retrieved from: https://bit.ly/3Gi7Hem

Miao, Q., Newman, A., Yu, J. \& Xu, L. (2013). The relationship between ethical leadership and unethical proorganizational behavior: linear or curvilinear effects? J. Bus. Ethics (2013) 116: 641- 653. Retrieved from: https://www.researchgate.net/profile/Jia-Yu-8/publication/257541913.pdf

Naim, M. F. \& Lenka, U. (2017). Development and retention of generation y employees: a conceptual framework. Employee Relations Vol. 40 Issue: 2 pp. 433- 455. Retrieved from https://bit.ly/2Zons 2 w

Naimi, N. J., Nathan, L., \& Hargraves, I. (2015). Values as hypotheses: design inquiry, and the service of values. Massachusetts Institute of Technology Design Issues 31(4). https://www.jstor.org/stable/43830434

Nasyira, M. N., Othman, M., \& Ghazali, H. (2014). Predictors of intention to stay for employees of casual dining restaurant in Klang Valley area. International Food Research Journal, 21(3). 863-871

Nedelko, Z. \& Brzozowski, M. (2017). Exploring the Influence of Personal Values and Cultures in the Workplace. USA: IGI Global.

Nikulina, I. E. \& Khomenko, I. V. (2015). Cognitive management: theory and practice in the organization. Procedia- Social Behavioral Sciences 166 (2015) 441- 445. https://doi.org/10.1016/j.sbspro.2014.12.550

Petrović, M. D., Jovanović, T., Marković, J. J., Armenski, T., \& Marković, V. (2014). Why should gender differences in hospitality really matter? A study of personnel's service orientation and job satisfaction in hotels. Economic research-Ekonomska istraživanja, 27(1), 799-817. https://doi.org/10.1080/1331677X.2014.975516

Pinar, M., McCuddy, M. K., Birkan, I., \& Kozak, M. (2011). Gender diversity in the hospitality industry: an empirical study in Turkey. International Journal of Hospitality Management 30, 73- 81. Retrieved from: file:///C:/Users/Jom\%20A.\%20Martinez/Desktop/Gender\%20Diversity.pdf

Pryce, J. (2014). Work values: A formidable domain within the context of people's lives. eTropic: electronic journal of studies in the Tropics, 13(2). https://doi.org/10.25120/etropic.13.2.2014.3311

Rao, B. \& Urs, V. (2017). Work values of generation Z work force. Academia. Retrieved from:

52 Consortia Academia Publishing (A Partner of Tourism Educators and Movers of the Philippines) 
https://www.academia.edu/41854452/A_study_on_work_values_of_Gen_Z_workforce_1_

Shuffler, M. L., DiazGranados, D., \& Salas, E. (2011). There'sa science for that: Team development interventions in organizations. Current Directions in Psychological Science, 20(6), 365-372. https://doi.org/10.1177/0963721411422054

Sobaih, A. E., Coleman, P., Ritchie, C., \& Jones, E. (2011). Part-time restaurant employee perceptions of management practices: An empirical investigation. The Service Industries Journal, 31(11), 1749-1768. https://doi.org/10.1080/02642069.2011.573659

Starrat, R. J. (2013). Ethical leadership. New Jersey: Wiley- Blackwell Publisher.

Tang, N. (2021). Cognitive abilities, self- efficacy, and financial behavior. Journal of Economic Psychology 87 (2021) 102447. Retrieved from https://bit.ly/2XKJOe0

Winter, R. P., \& Jackson, B. A. (2016). Work values preferences of Generation Y: performance relationship insights in the Australian Public Service. The International Journal of Human Resource Management, 27(17), 1997-2015. https://doi.org/10.1080/09585192.2015.1102161

Witzel, M. (2018). The ethical leader. London: Bloomsbury Publishing Plc

Zydziunaite, V. (2018). Leadership values and values-based leadership: what is the main Focus. St, Ignatius of Loyola College, Kaunas, Lithuania. 
Martinez, J. R. A.

54 Consortia Academia Publishing (A Partner of Tourism Educators and Movers of the Philippines) 